\title{
THE ORIGIN OF THE RULE AGAINST UNJUST DISCRIMINATION.*
}

Side by side with the common law obligation of public servants to render service to all who apply and to render such service for reasonable compensation, there admittedly now exists in America, apart from statute, the obligation to serve without unjust discrimination either in the matter of rates or of service; while in England, in rates, at least, and probably in the matter of service, the same duty prevails. The two former obligations are of early origin, dating back to the Year Book times, and have been recognized for centuries. As to the last, the few modern writers and cases which have entered upon an investigation of its origin are at variance both as to whether or not such a duty existed at the common law, and, if not, as to the precise time when it made its appearance. It has been regarded by some as an ancient common law doctrine of which the early statutes were merely declaratory, and passed "in abundance of caution" merely to affirm "the common right to equal justice which exists independent of such provisions" ; ${ }^{1}$. while others have considered it a wrong recently recognized, but have frequently disagreed as to the exact date of its origin."

When we look to the early text-books to discover the views of writers of these periods concerning the existence of such 2 duty, we find a situation that is confusing, that abounds in contradictions, and that as a whole sheds little light upon the problem. Among the English authorities, Chitty affirms the existence of the rule but all the cases cited in its support were de-

* This is the first of a series of articles by the writer dealing with certain 2spects of the doctrine of unjust discrimination in its relation to public servants, -including its origin, its scope at common law and under the statutes, and certain problems involving the doctrine arising under the Interstate Commerce Act and kindred legislation, which have seemed worthy of investigation.

${ }^{2}$ Per Lewis, C. J., in Sandford y. Railroad Co., 24 P2. 378 (1855). "The supposed necessity for such provisions in charters granted in this country and in England, proves nothing more than that the lawmakers of both countries were apare of the difficulty in holding large corporations to those common obligations of justice which individuals feel bound to acknowledge without legislative ensetment."

"Wyman, "Public Service Corporations" (1911), Vol, 3 Sec. 1282 
cided under "equality clauses" which were statutory requirements imposed by Parliament for the express purpose of securing equality. ${ }^{8}$ Powell, in his Law of Inland Carriers in 1861, after denying the existence of any obligation to charge equally, later in his work states that unjust discrimination was probably illegal independently of any statute. Other writers do not attempt a discussion of the rule at common law, but consider it only under the restrictive railway legislation. ${ }^{3}$ The view of Story in his treatise on Bailments, the leading early American authority on the subject, is interesting. In enumerating the duties and obligations of common carriers the editor of the seventh edition in 1863 inserted this sentence: "And he has no right to charge one higher rates than he serves others for." The editor of the eighth edition, seven years later, inserted the opposite view at length:?

"But at common law a common carrier of goods is not under any obligation to treat all customers equally. $\mathrm{He}$ is bound to accept and carry for all, upon being paid a reasonable compensation. But the fact that he charges less for one than another is only evidence to show that a particular charge is unreasonable; nothing more. There is nothing in the common law to hinder a carrier from carrying for favored individuals at an unreasonably low rate, or even gratis."

This was repeated in a note in the ninth edition in 1878 .

The development of the rule in England and in America has been entirely distinct. In England the duty was enforced by legislative action before a common law remedy for the abuse of unjust discrimination had an opportunity to develop. In America, in the absence of a statutory remedy, the common law worked out a remedy more or less adequate, which was later to be supplemented by statute. The origin of the duty in England and in America will therefore be considered separately.

\footnotetext{
"Chitty, "Carriers" (1857), p. 7t.

"Second ed., pp. 202 and 273

"Walford, "Railways" (2d Ed.), (1850), p. 317.

"Story "Bailments," 7th Ed., See. 508

'Id, 8th Ed, See, 508
} 


\section{The Origin of the Rule in Englawd.}

Whether or not there existed prior to that time in England a common law prohibition against unjust discrimination, we find until the middle of the nineteenth century a singular and rather significant absence of authority upon the subject. The doctrine is conceded to be of recent origin, having its inception in the latter half of the past century. The only earlier case in which the problem was even suggested or adverted to is Lces v. Manchester \& Ashton Canal Co., decided in 1809. By statute a certain canal company was authorized to take tolls up to a certain maximum and to reduce them at a general assembly held upon certain notice. A contract was made without calling a general meeting, whereby in consideration that certain individuals would make cuts to convey water and send all their coal by the canal, they were to be allowed to use the canal at a reduced rate, the company paying back a rebate. The plaintiff brought suit to recover the rebate. The reporter states that the questions were raised at the argument "whether the contract in question were lawful within the provision and spirit of the canal acts respecting the reduction of tolls . . . or as being a partial reduction of tolls for the benefit of particular individuals only, and not of the public" He states that the court considered at the time that there was great weight in the last class of objections urged on the part of the defendants, and held the case over for consideration on these grounds. Lord Ellenborough, who delivered the opinion of the court, held the agreement void because it was not made at a general meeting, and upon this ground disposed of the case. He stated further, however, that "they (the public) also have an interest that the tolls shall be equal upon all; for if any are favored, the inducement to the company to reduce the tolls, gererally, below the statute rate is diminished. But as it is sufficient in this case to say that this bargain is not binding upon the company of proprietors, inasmuch as it abridges their rights in a way the statutes do not warrant, it is unnecessary to give an opinion whether.it so inter-

- 11 East 645 (1809). 
feres with the rights of the public, as to be on that ground also void."

The opinion of Lord Ellenborough is most interesting, since it suggests, at an early date, an argument founded upon public policy that would justify a common law prohibition of unjust discrimination entirely apart from statute, and also for the additional reason that it represents an isolated early instance of the mention of this modern doctrine, which cloes not appear again in the reported cases until half a century later. And in view of the more modern development of the rule prohibiting unjust discrimination, the reasons that would have influenced Lorl Ellenborough, had he been compelled to adopt such a rule to attain the result he desired, are of interest in that they represent the attitude of a great legal mind upon the prohibition of unjust discrimination, when a situation suggesting it first came before the courts. It does not appear that he would have worked out the problem on the theory that there exists an abstract right on the part of every member of the public to enjoy equality of treatment. The obligation on the part of public service companies to serve for a reasonable compensation had long been recognized, and the court here suggests that to permit certain individuals to receive undue preferences, will diminish the inducement which might otherwise be present to grant a general reduction of the rates. He seems to suggest that there may be a rate intrinsically unreasonable which is not so strikingly and obviously disproportionate to the cost of service that an effort to secure its reduction by legal process would be successful. It is the same argument advanced in the debates in the constitutional convention in Pennsylvania, in 1873 , when the clause prohibiting free passes was being discussed, - namely. that such a system involves an expense which must in the nature of things be borne by that part of the traffic which receives no favors. Furthermore, the granting of favors to individuals would probably prove an effective method of quieting a powerful or restless opponent of rates that were intrinsically woreasonable. Both of these factors indicate the intimate relationship which the prohibition of unjust diserimination bears to the 
ancient obligation to serve for a reasonable compensation, and this early case shows that the rule prohibiting unjust discrimination may be an outgrowth of the obligation to demand only a reasonable compensation, and not an extension of the duty to render service, as it is generally considered. Certainly its relation to the former obligation, as this early case indicates, is very intimate.

The existence or non-existence of a common law prohibition against unjust discrimination in England became for most purposes of only acadernic importance at a very early date. Almost as soon as the incorporation of railroads began in that country, there were inserted in the private acts of incorporation the so-called "equality clauses" providing for uniformity of treatment and placing all patrons similarly situated upon an equality in their relations with the railroad. The first of these clauses appears to have been introduced during the fourth year of the reign of William IV. After that date the custom of inserting such clauses in railway charters became universal.

The early statutory protection in England against unjustly discriminatory practices such as those which grew up in America under an uncertain or ineffective common law rule, may perhaps be accounted for by the precedents existing there in the earlier canal and turnpike acts. The Act of $3 \mathrm{Geo}$. IV, in 1822, contained a typical provision imposing a fine of five pounds for the collection of a greater or less sum than the published toll, the forerunner, possibly, of the penal clauses in the modern acts, which have been thought necessary to render the remedy effective. The first important general statute upon the subject in England was the Railway Clauses Consolidation Act, passed in 1845, which embodied in a single general statute the various provisions that theretofore had been inserted in private acts of inforporation. It provided for uniformity and equality of rates, and though less explicit and comprehensive than the act of 1854, it was calculated to serve the same purpose.

A search of the parliamentary debates during the period in which the act was. under discussion in parliament fails to disclose any debate upon the section making provision for such 
equality. It was adopted, apparently, without any general discussion. It is possible that during the years in which equality clauses were the rule, the people had become so accustomed to provisions of this character and understood their inlerent justice so thoroughly that no objection was made to a general provision of that kind. $\mathrm{Or}$ it is possible that a proposition so ubviously just and fair, even though not theretofore recognized as a general principle of law apart from the specific mandates of acts of incorporation, would fail to arouse serious objection on the part of fair-minded legislators. The more natural conclusion, perhaps, from the absence of parliamentary debate. would be that both the act of 1845 and the earlier "equality clauses" were, as many American cases have maintained, merely declaratory of a common law rule of long standing: Although carriage of goods by sea early became an important factor in commercial life, the cases involving sea carriage throw no light upon the subject under consideration until a comparatively recent date. The law respecting sea carriers was usually said to be the same as that applicable to carriers by land, the only difference being that in the case of sea carriers a somewhat broader conception of "acts of God" prevailed. It was probably the prevalence of the charter-party as a contract of affreightment that deferred the litigation of ocean rates until a later date.

In view of that fact that the "equality clauses" in the early charters of incorporation uniformly imposed an affirmative obligation to afford impartial service to all, the references in the early cases in which these clauses were construed regarding the state of the common law on the subject of unjust discrimination are merely dicta. The earliest dictum occurs in Basendale v. The Eastern Counties Raihway ${ }^{\circ}$ in 1858 , and this dictum is often cited alone as authority for the proposition that no doctrine of the common law required equality of rates, if the rates offered were not inherently unreasonable. The case arose under an "equality clause," and Willes, J., in the course of his opinion expressly said: "It is unnecessary to consider how the matter would stand at common law." In the course of the argument of the

4 C. B. (N. S.) 63 (1858). 
case, as it is reported, Williams, J., quoted an excerpt from the note to Coggs v. Bernard in the fourth edition of Smith's Leading Cases 10 which stated, apropos the obligations of common carriers, that "the hire charged must be no more than a reasonable remuneration to the carrier, and, consequently, not more to one (though a rival carrier) than to another, for the same service." Byles, J., thereupon said: "I know no common law reason why a carrier may not charge less than what is reasonable to one person, or even carry for him free of all charge"; and Willes, J., in his opinion, referred to the passage from Smith's Leading Cases quoted above as "undoubtedly inaccurately expressed."

Four years later in a case which likewise arose under an "equality clause," a situation was presented where a common carrier had established certain rates for packed parcels which were higher than the rates charged for small parcels. An action was brought to recover for the exaction of rates alleged to be excessive upon a shipment from Boulogne to London. The court refused recovery on the ground that the contract had been made in France, and as there was nothing in the lcx loci contractus which rendered the inequality illegal, no action could be maintained. Mr. Chief Justice Earle, who delivered the main opinion, justified the decision even if it were assumed that the "equality clause" was applicable, on the ground that it was a proper classification. Willes, J., after concurring in an opinion in which he approved the grounds stated above, concluded his own opinion with these words: "the obligation of the carrier at common law being to charge reasonably, but not to charge equally." ${ }^{11}$ The decision was based on the ground first stated; the further observation by Willes, J., is dictum.12

*. 174

"Branley v. S. E. Railway Co, 12 C. B. (N. S.) 63 (1862).

- In Garton v. Bristol \& Exeter Ry. Co, I B. \& S. 112 (1861). it was held that one charged a reasonable rate could not recover the difference between his rate and that charged another in an action for money had and received. Such actions involve the complicated question of the right to recover money paid under a mistake of fact, and the case therefore did not necessarily decide that an equal rate for the future could not have been comnelled by mandamus. 
In Great Western Railroad v. Sutton ${ }^{13}$, decided in the House of Lords in 1869, the question arose whether or not it was proper to charge one engaged in the business of collecting small packages and forwarding them in packed parcels a higher rate than a wholesale dealer who shipped similar packages was compelled to pay. A judgment in favor of the shipper, who was the plaintiff in the case, was upheld by the House of Lords. The case turned upon the determination whether or not under an "equality clause" such a difference in rates was justifiable, and the state of the common law upon the subject nas entirely irrelevant. Mr. Justice Blackburn, however, at the beginning of his opinion, in recounting the common law obligations of common carriers, said: "At common law a person holding himself out as a common carrier of goods was not under any obligation to treat all customers equally," and further on, "There was nothing in the common law to hinder a carrier from carrying for favored individuals at an unreasonably low rate, or even gratis," citing as authority for this statement the dicta by Byles, J., and Willes, J., in the two cases last referred to. Speaking of "equality clauses," he says: "At first the legislature in each special act inserted such clauses as seemed, to the particular committees, reasonable in each case Very soon those came to be the usual clauses which the then chairman of Committees of the House of Lords used to require to be inserted in all railway bills with more or less modification. They wero known by his name as 'Lord Shaftsbury's clauses.' Finally, in 1845 , the legislature embodied in a general act ( 8 \& 9 Vict. c. 20) those clauses which it was thought expedient should generally be inserted in railway acts"

It is natural that the early cases involving the subject of unjust discrimination were almost invariably cases involving preferences in rates or charges, rather than in facilities and accommodations. The problem of unjust discrimination in its acute and complicated phases is one that becomes of more frequent and natural occurrence with the introduction of improved

'I. R. 4 H. of L. 226 (1869). 
facilities and accommodations, of tank and refrigerator cars, of grain elevators and private sidings. It is interesting, thereforc, to note what appears to be the earliest case in which the problem of discrimination in the matter of facilities was presented.

The alleged preferences included the supply of stationery by the railroad to a certain coal company, and the use of railroad stations for advertising purposes. The favored company was allowed to employ porters and clerks of the railroad, and passes were given agents of the coal company. They were also given a longer period to unload their cars without demurrage charges, and in addition were given lower rates. The court held that the guaranty of large shipments which the coal company undertook was sufficient to justify the difference, provided the carrier was willing to enter into similar agreements with others; and that the arrangement being made with a view to profit for the carrier and not merely for the purpose of favoring a particular shipper, the statutory requirement of equality was not violated. ${ }^{14}$. The strict construction adopted in applying the "equality clauses" in many of the early cases constitutes some evidence that there was no prohibition of unequal treatment at common law. 18

As has been stated, courts and writers have differed widely as to whether any rule against unjust discrimination existed at common law in England. The writer has found one case, which, it is submitted, raises the question squarely an 1 decides it. - It is cited in a text book by Powell on The Law of Inland Carricrs. The authorities usually cited in support of the non-existence of any common law rule against unjust discrimination are (1858)

${ }^{2}$ In re Nicholson \& The Great Western Railway Co, 5 C. B. (N. S.) 366

"In Attorney General v. The Birmingham \& Derby Junction Ry., a Railway \& Canal Cases 124 (1840), the earliest case arising under an "equality $8 s_{\text {, }}$ while passengers going from $A$ to $B$ and thence to $C$ were only charged 25 . between $A$ and $B$. The court refused to order the discontinuance of the diserimination, holding that it was merely differences under circumstances precisely similar that the "equality clause" was designed to prevent. Whether the circumstances were sufficiently dissimilar to justify 2 difference in rate, the court did not inquire. This strict construction of the "equality clause" is some evidence of the non-existence of any prohibition of unjust discrimination at common law. 
the dicta in the several cases mentioned above. While these are often clear and positive, they occur in cases governed by other considerations, and can rise to no higher dignity than dicta.

In Hurgerford Market Company v. The City Stransboat Company, ${ }^{10}$ reported in the Law Journal Reports of 186r, the court. faced the situation squarely: The Market Company was authorized by a clause in the act under which it was incorporated to take from every passenger landing or embarking from the wharf which they were to erect, a toll not exceeding ad. for each passenger. The company, the plaintiffs in the case, charged the A Steamboat Company, the defendant, a higher. rate per passenger than they charged the B Steamboat Company. There were no differentiating circumstances alleged as a justification for the disparity in rates, nor did the rate charged the defendant company exceed the maximum which the statute authorized. The defendant, upon being sued for tolls, objected to paying more than its rival, but recovery of the full amount was allowed.

Mr. Chief Justice Cockburn, who delivered the opinion of the court, after reviewing the facts of the case, said: "We have, therefore, to consider whether a company entitled to take tolls in return for a public service is bound independently of express provision, to exact the same tolls from all persons alike, or is at liberty, if so minded, to remit the tolls or any portion of them to particular individuals, at its pleasure and discretion. No authority has been adduced for the former of these propositions. ${ }^{17}$... The result, then, is that, in our opinion, there neither arises upon these acts of parliament, nor exists at common law, any obligation of this company to exact uniform

* 30 Law Journal Reports 25 (1860); 3 EL \& El 365.

"Continuing, the court said: "In Lees $Y$. The Manchester \& Ashton Canal Company the observations of Lord Ellenborough go no further than to show that, on grounds of public policy, it may be desirable that such an obligation should attach to the power of a public company to take toll, yet 2uthority would certainly seem to be required to establish a proposition
directly $2 t$ variance with the well-known $2 x$ iom that every one is at liberty to renounce 2 right established in his favour. The power to take tolls is
conferred on the company in consideration of service to be renderzd and the conferred on the company in the public. If the service be sendered, and the accommodation afforded, the obligation of the company is fulfilled. 
tolls, provided they keep within the amount fixed and appointed conformably to the iI Geo. IV c. LXX, and that consequently our judgment must be for the plaintiffs."

The court did not, in its opinion, cite the dictum of the earlier case of Baxendale v. Eastern Countics Railway, ${ }^{18}$ nor did the House of Lords in enunciating this doctrine by way of dictum in $1869^{10}$ advert to this case. It having been established that no statutory mandate compelled the imposition of equal rates upon all users of the wharf, and it having been conceded that the owners were engaged in public service, the question was squarely raised whether or not, aside from any statutory provision, an obligation to charge equally was imposed by the common law. The court decided flatly that no such duty existed.

In the argument of the case reference was made to the carly turnpike acts to prove that such a rule existed at common law. In these acts express power was conferred upon the trustees to compound with individuals or communities under certain circunstances in the fixing of tolls, ${ }^{20}$ from which it might have been inferred that in the absence of such express power to compound, no authority to do so existed. But in the Hungerford Case the court held that since in its operations as bridge owner the company was by its statute of incorporation compelled to charge equally, the failure of Parliament to insert a similar clause in the act authorizing the erection of the wharf at 2 time when such clauses were in common use, showed an intention to relieve them of this restraint, and refused to accept the suggestion of counsel that the compounding clauses in the early turnpike acts implied a common law requirement of equality.

It may, therefore, be safely asserted, that under the common law in England no prolibition against unjust discrimination on the part of public service companies existed. When, however, we regard the situation in its practical.aspect, apart from legal authority, it is difficult to conceive that the obvious injustice of such discrimination should have been allowed to

- Supra, note 9

- See supro, note 13.

$\approx$ See 3 Geo. IV, c. 126, Sec. 42, and 4 Geo. IV, c. 95, Sees, 12 and 13. 
continue with no remedy for redress. As early as the Year Book times the regulation and supervision of public servants had reached an advanced stage. The duty to serve for reasonable compensation was very early established. Iikewise the obligation to serve all who applied for service was of ancient origin.

The doctrine of unjust discrimination in its essence is not primarily concerned with the intrinsic reasonableness of rates nor with extortion; it is concerned rather with the question of relative equality and the fact that a favor to one results in injury to another.

But in Lees v. Masuchester \& Ashton Carral Co., ${ }^{22}$ the earliest case in which a discriminatory situation was judicially considered, the undoubted tendency of preferences to result in the creation of a general scale of rates intrinsically though perhaps not obviously unreasonable, is considered of itself as probably a sufficient reason for their prohibition. Furthermore, at the early law, one of the most cogent reasons mentioned by the courts for the enforcement of the duty to serve was the injurious monopoly that would otherwise result. Such a situation was regarded as prejudicial to the public welfare, and to permit a single manufacturer or shipper to thrive in a field free from competition owing to the refusal of a common carrier to serve his rivals, was so obviously in contravention of public policy that the early courts were not hesitant in applying the stamp of disapproval. But if the courts believed that by requiring a reasonable rate without any further restriction as to charges the creation of monopolies could be prevented, subsequent history has demonstrated their error. For within the limits of any nonconfiscatory maximum rate yet prescribed there is sufficient leeway for favoritism and unjust discrimination to create the very monopolies that the common law abhorred. Impressed as they were with this monopoly idea, it is hard to believe that the courts would, especially during the early days of stringent public service regulation, have permitted a carrier to charge one patron a

- Supre, note 8 
greater sum than it charged another for the performance of an identical service, and under similar circumstances, even if it were conceded that the higher sum was not unreasonable. One of the most puzzling problems in the law of public service is the belated appearance in the reported cases of the obligation to refrain from unjust discrimination.

It is during this period prior to the middle of the nineteenth century when judicial expressions upon the subject of unjust discrimination are wanting, that the economists' views of the subject are of especial value. And as to conditions existing prior to the year 1870 the works on railroad economics are rather vague. The belated regulation may have been due entirely, or in part, to any of three causes.

Dr. Emory R. Johnson, in his excellent recent work on railroad economics, attributes it to the absence of competition among the early carriers. ${ }^{22}$ So long as a carrier has a substantial monopoly of the business of transportation there is no incentive to favor one shipper at the expense of another, but as soon as competition is encountered, concessions must be allowed to secure patronage which would otherwise be diverted to a rival, and the complaint against unfair discrimination arises. Not until rail carriage became usual did the problem become acute. In the case of passenger traffic, aside from the free pass abuse, the situation has never become serious. Almost as soon as railroad transportation was introduced in England this obligation was enforced by statutes; until that time the most plausible explanation, perhaps, of the absence of any such obligation, is that competition had not reached a state that required such a regulation.

It may, also, have been due to the early attitude which did not sanction interference. with freedom of trade and of commercial contracts, and to the general feeling that one should be allowed to dispose of his commodities at his own price, free from any outside interference approaching paternalism. It may have been thought that to fix a maximum or reasonable rate

"Johnson: "American Railway Transportation," Ed. 1915. 
constituted a sufficiently serious interference with this freedom of commercial conduct.

A third possible explanation, in America, for its late appearance is that these discriminations were so well concealed that their extent was not generally known, a circumstance which may account for the absence of litigation. In the period following the year 1870 when commissions of investigation were disclosing the extent of the widespread practice of granting rebates, the popular surprise at its prevalence indicates that the full extent. of the abuse had not been fully appreciated by the general public. These investigations disclosed, further, that in many instances the contracts under which these preferences were created specifically enjoined secrecy on the party of the second part.

The work of many of the economists upon the subject is so biased as to be of little value. Between those writers who maintain that railroads have never made a rate difference which was not justified by some economic principle such as competition, and that the early rate statutes are merely "statutory monuments of ignorance and affected solicitude," 2 and those of the other school who fail to see any but sinister motives behind every rate inequality, there lies a broad field embracing many disputed economic principles, and there exists a mass of information that is interesting, contradictory, and unauthenticated. Save for a few writers, the whole is marred by an ill-concealed partisanship. In one view, however, there is a tendency to concur, namely, that prior to the year 1870 and the legislation of the decade following there was at least no effective curb against practices that were unjustly discriminatory. ${ }^{24}$

-Kirkman: "Railway Rates and Government Control" (1892), p. 125. See also Aeworth, "The Elements of Railway Economics" (1905), P. i3I.

"In Drinker's "The Interstate Commerce Act" Vol I, p. 60, the defects of the common law as a remedial weapon are indicated. The situation from the point of view of the economist is ably and impartially summarized by Professor Hadley in his work on "Railroad Transportation" (1886), 2. 22:

"This condition of things became obvious about 1870; and it is againat these evils and dangers that the subsequent legislation has been almost entirely directed The years $1870-3$ are marked by a change in the aims of sailroad legistation, more obvious perhaps than the chavge in principles of 
The investigation, however, has disclosed that the legal aspect of the problem is clear and free from doubt. However strange it may seem that no such rule was developed, and despite frequent statements by courts and writers to the contrary, there was no prohibition of unjust discrimination at the English common law.

\section{Tye Origin of the Rule in Ayerica.}

The cases involving the duty of railroads to grant accommodations to all express companies which apply for service will be considered in a subsequent article. The basis of decision in these cases does not essentially involve the true doctrine of unjust discrimination. The earliest case dealing with this rule in America is Fitchburg Railroad v. Gage, ${ }^{23}$ a case decided by

railroad management twenty years earlier. A noticeable thing abour the changes of legislation was the suddenness with which they made themselves felt all over the world. Hitherto the object had been to secure rapid increase of railroad facilities. With this end in view England allowed the utmost freedom from restriction; and United States granted almost reckless subsidies of land, or guaranteed bonds; on the continent of Europe some states gave direct pecuniary assistance to private companies, other states built railroads themselves. The most they feared was that the charges in general might be too high, and this they sometimes sought to prevent by law. That the community might be injured by the reduction of some charges more than others scarcely entered the minds of the majority of legislators and statesmen. The very worst forms of discrimination were given by the state railroads themselves, apparently without suspicion of harm.

"The reaction was. sudden and widespread. In the years immediately following 1872, the Granger movement did its work in the United. States: the Railway Commission was established in England; Belgium and Prussia determined to change from a mixed system to 2 system of state ownership pure and simple; France and Italy began 2 policy-eventually unsuccessfulof state purchase and management. The general object was the same in cvery case. Hitherto legislation had been conceived from the standpoint of the investor - whether the investor was a private company or the state itself, mattered little. Henceforward things vere looked at from the standpoint of the shipper, and especially of those shippers who under the old system were being driven to the wall.

"It can hardly be doubted that the reaction was a healthful one in itself. It is still more certain that it was often carried to an unfortunate extreme. It is safe to say that a large part of the railroad legislation of the past twelve years could never be carriẹd out at all, and that a large part of the remainder would do more harm than good to all concerned. The attempt to legislate for the shippers without regard to the railroads is 25 much of 2 mistake as the attempt to legislate for the railroads without regard for the shippers. To reconcile these two interests-apparently conflicting and yet mutually depenclent upon onc another. is one of the most serious problems of modern business or modern politics."

* 12 Gray (Mass.) 393 (2859) 
the Supreme Court of Massachusetts in 1859. In that case an action was brought by a railroad company for the recovery of freight charges upon certain goods shipped by the defendant. The defendant objected to the amount of the charges, not upon the ground that they were inherently unreasonable or excessive, but because freight was carried for others for a lower rate under similar circumstances. Full recovery of the higher rate was ajlowed.

It is highly significant that at the time this case was decided, while it purported to follow the English common law, there were at that time in England neither flat decisions nor clear dicsa indicating what the common law upon the subject of unjust discrimination was. This may therefore be regarded as the earliest case in which the question of the existence of a common law obligation was passed upon either in England or in America. The language of Mr. Justice Merrick in the opinion has often been quoted:

"The recent English cases, cited by counsel for the defendants, are chiefly commentaries upon the special legislation of parliament regulating the transportation of freight on the railroads constructed under the authority of the government there; and consequently throw very little light upon questions concerning the general rights and duties of common carriers, and are for that reason not to be regarded as authoritative expositions of the common law upon those subjects. The principle derived from that source is very plain and simple. It requires equal justice to all. But the equality which is to be observed in relation to the public and to every individual consists in the restricted right to charge, in each particular case of service, a reasonable compensation, and no more. If the carrier confines himself to this, no wrong can be done, and no cause afforded for complaint. If, for special reasons, in isolated cases, the carrier sees fit to stipulate for the carriage of goods or merchandise of any class for individuals for a certain time or in certain quantities for less compensation than what is the usual, necessary and reasonable rate, he may undoubtedly do so without thereby entitling all other persons and parties to the same advantage and relief."

Thus in the earliest Arserican case the rule was laid down that no common law prohibition of unjust discrimination existed, and it was assumed that the common law of England was 
in accord; although the precise state of the English law at that time was not indicated in any reported case, and no authority upon that point was cited. In laying down the broad doctrine, the court did use the words "for special reasons" and "in isolated cases," suggestive of the "justifiable discrimination" of the later common law, a situation in which an inequality of treatment-is held to be justified in certain cases of dissimilarity of circumstances. But under the facts of the case as stated there appear to have been no differentiating circumstances which would limit the scope of the decision and the applicability of the broad language of the opinion. The ratio decidendi in the solution of this problem when presented for the first time to an American court seems to be the same as that adopted by the English courts later in arriving at the same conclusion. Under the court's method of reasoning, early authorities are cited defining the extent of the carrier's obligations to the public, wherein the duty to serve all indifferently and for a reasonable remuneration is emphasized. It seems then to have been inferred by the court, although it is not expressly so stated, that this enumeration of the obligations of carriers in the early authorities was exclusive, and that therefore no restriction of unjust discrimination existel. Whether at any time the duty to serve impartially may have been tacitly accepted as a necessary corollary to the well-recognized duty to serve all who applied, or whether, as these early cases indicate, regulation had not advanced to such a stage that this obligation became a common law duty, must remain a matter for speculation. Upon either theory, the long-continued absence of judicial reference to the subject. is explainable.

The case usually cited as the earliest departure from the rule announced in Fitcliburg Railroad v. Gage, and the one gencrally supposed to have first laid down the rule against unjust discrimination in America is Mcsscrsger v. Pcunsylzania Railroad, ${ }^{26}$ decided by the Court of Errors and Appeals of New Jersey in 1874. A shipper of goods sued to recover certain rebates on goods shipped which the railroad had promised to re-

$=8$ Vroom (N. J.) 531 (1874). 
mit. The court refused recovery, saying that a common carrier could not legally give "unequal preferences," and said that this rule had been laid down by the cases at common law in America. The precise ground of decision in the early cases involving the rights of express companies.upon railroads, before-referred to, here becomes important, as this leading early decision relies upon the authority of these previous cases, which involved an entirely distinct obligation, as the-sole authority for the rule that it announced. ${ }^{27}$ The court concludes that at common law there is "necessarily implied a duty on their [the carriers'] part, and a right in the public, to have fair treatment and immunity from unjust discrimination."

Although the Messenger Case is quite generally cited as the turning point in the American common law, at which it departed from the rule of the Gage Case, a common law rule prohibiting unjust discrimination had, in fact, become well established in America several years earlier. It is rather notable that none of the earlier cases except those involving the rights of express companies were cited by the court to sustain its conclusion, since there existed authorities perfectly apposite that were not referred to.

It is here proposed to consider chronologically those cases decided prior to the Messenger Case wherein the illegality of unjust discrimination was recognized, and wherein the true beginnings of the common law prohibition of unjust discrimination in America are discernible.

The earliest of these cases antedates by two years the famous Gage Case, in which the existence of any such duty was denied. ${ }^{28}$ In this case a railroad regulation provided that a certain excess fare should be charged when passengers neglected to purchase tickets before boarding trains. The plaintiff refused to pay the excess and being ejected from the train, sought recovery from the railroad. The regulation was held valid.

- New England Expsess Co. y. Maine Central R. R. Co. 57 Me, 188 (1869); McDuffee v. R. R, 52 N. H. 430 (1873) ; Sandford v. Railroad, 24 $P_{2} 378$ (1855). The court also cited Audenried v. P. \& R. R. R, 68 P2 370 (1871), which is not an "express" case and only by a very general dictum supports the decision.

- C. B. \& Q. R. R. v. Parks, 18 IIL 40 (1857). 
In its opinion the court emphasized the fact that additional trouble was caused and an increased service reqiired of the railroad in such cases, and seems to have justified the excess charge as a reasonable remuneration for this extra service required. But Mrr. Justice Caton, in the course of his opinion, announced, by way of dictum, the rule against unjust discrimination, which, though mere obitcr, has an interest as the earliest pronouncement of the rule in the American common law. The court said: "These charges, however, must be uniform; that is, the charge should be the same for all persons similarly situated, and for all freights of a like kind and quality for a given service," and further on, "they may not say that they will charge A twice as much as they do the public in general." Then follows a sentence at odds with the preceding. and containing a contradiction within itself: "While they show favor to individuals or classes, by carrying them free or for half price, if they choose, they cannot be allowed to arbitrarily oppress an individual, by charging him an unusual price, simply because it is him." It is possible that the last sentence was meant to suggest the wholly discredited idea that there is a difference in legal principle between arbitrarily allowing A greater privileges than other members of his class, an "undue preference," and capriciously denying to B privileges which the fellow members of his class are permitted to enjoy, sometimes called in contradistinction an "unjust discrimination." The first statement constitutes a statement of the law substantially as it was laid down in the Messenger Case some years later. But in the latter case it was not referred to.

The first case in America in which the question was squarely raised and the rule against unjust discrimination laid down is Twclls v. Pcrusylvania Railroad, 20 decided by the Supreme Court of Pennsylvania in 1863 . That this early. case dealing with the problem was not cited in the later cases wherein the identical problem was treated as res nova in the American law, is probably due to the fact that either through accident or because it was marked "not to be reported" it was omitted from

- 2 Walker (P2.) 450 (1863). 
the Pennsylvania reports of that year, and it was first made available upon the publication of Walker's collection of unreported cases in 1890 .

The railroad had established a higher rate from Pittsburgh to Philadelphia upon freight-sent by the-complainant which was intended for further shipment to New York, a point beyond its terminus, than when Philadelphia was its final destination. It was not contended that the higher charge was inherently unreasonable; it was merely urged that the fact that the ultimate destination of the freight was beyond the carrier's line did not create a dissimilarity of circumstances upon which an inequality of rates could properly be predicated. The court held that the discrimination was unjustifiable. After enumerating some of the duties of common carriers, Mr. Justice Strong concludes with the mention of the duty to transport "at rates of compensation that are alike to all." The court by way of.dictum suggests that an inequality or special concession may be justified if in allowing it the carrier has only its own interests in view and does not act out of a desire to favor any certain shipper. Precisely the same doctrine crept in under the English equality clauses, and if these legislative efforts did not exclude it, it is not surprising that the common law hesitated in prohibiting a preferential arrangement which to the carrier represented a sound and wise economic policy. It is this view that, consistently adhered to, would justify the application of the so-called "wholesale principle" in freight rates to its fullest extent, permit the large shipper to eliminate his smaller competitor, and justify a difference of charge, based upon competition, to two shippers in the same city, one of whom is so situated that he can secure switch connection with a rival railroad. This conservative attitude on the part of the court in circumscribing the rule is characteristic throughout the early history of the rule prohibiting unjust discrimination, but it was not destined to survive

The court cites no authorities directly sustaining its position, seening to accept without question the obligation to refrain from unfair preferences. After mentioning the charter under 
which the railroad company was authorized to become a carrier and the powers given thereunder, the court says: "It is admitted that in the exercise of these powers they must treat all alike." Whether the court was of opinion that under the charter the railroad became more than a public servant, a quasi state agency which from its very nature must treat all alike, does not appear, although the opinion clearly seems to indicate that the duty was one incident to public service. Referring to the special provisions of the English charters specifically enjoining equality, the court said that these were merely declaratory of the common law, and cited Sandford v. The Railroad..$^{20}$

The next case involving the rule also arose in Pennsylvania. one year later." Here the complaint was that the railroad charged a lower rate on freight shipped from Pittsburgh to Philadelphia than it charged for an identical service when the freight started from a point outside the state, in this case, at IIhceling. The discrimination was a part of a general policy on the part of the railroad to facilitate the movement of intrastate commerce, since the State of Pennsylvania had imposed a tonnage tax upon freight originating within that state. the effect of which was to place Pennsvivania shippers at a serious disadvantage in competing markets. The avowed purpose of the rate difference in this case was to compensate for the tonnage tax and place the local shippers upon an equal footing with those outside the state boundaries.

The difference in rates was upheld by the court. The reduction of the rates upon local freight had been brought about by a mandate of the legislature in the Commutation Tonnage Act of $186 \mathrm{r}, 32$ which, realizing the limitations imposed by the federal constitution, wisely refrained from any attempt to prescribe interstate charges. So far as the usual justifications of discrimination are concerned, such as variances in the cost of scrvice or competition, the difference in rates here sustained was entirely capricious and arbitrary. Yet in the decision of the

$=24 . P_{2} .378$ (1855).

" Shipper v. P. R. R., 47 Pa. 388 (1864).

- Act of Mar. T, 1861, P. L. 88 , Sec. 2 
court the rule against unjust discrimination is clearly recognized. Citing Sandford v. Railroad, 38 the earliest of the "express" cases, the court holds that the English "equality clauses" were merely declaratory of the common law, and says that there is implied in the power given the carrier to establish reasonable rates the requirement that these rates must be "fixed, equal, and impartial." In holding that this discrimination in favor of local traffic was justified, the court said that while equality under the same circumstances was required, a discrimination based upon the place of production of the commodity was not necessarily an unjust one.

There is discernible in this case the conservative attitude, corresponding to that of the early English courts, in adopting a strict and narrow application of the requirement of equality. The distinction is made between unequal treatment of individuals and of localities. It is quite natural that the injustice of the former should have been first recognized. When A and B liv: ing in the same city are charged unequal rates for identical services rendered by a common carrier, or where services are rendered under circumstances not identical, but on the other hand not substantially dissimilar, and unequal charges are imposed, the discrimination is obvious. But when $\mathrm{A}$ and $\mathrm{B}$, living in different cities, are charged by the same carrier unequal rates to 2 third city, $X$, under circumstances substantially similar, the unjust discrimination, while as destructive and indefensible, is a little less obvious and striking. Even today, under modern statutes, competition may justify a discrimination between localities; between individuals, it cannot. While the court had a perfect conception of the injustice of preferences among individuals, it does not appear to have recognized that a discrimina. tion among localities could be illegal. Speaking upon this point, the court says:

"In no just sense can the adoption and enforcement of a rate of tolls for the transportation of merchandise which is the subject of domestic trade carried in the prosecution of such trade, and a different rate for similar articles imported and carried in the con-

- Supra, note $3 a$ 
duct of a foreign or extraterritorial trade, be regarded as a discrinination between individuals. The benefits of reduction on domestic trade are extended to all persons alike, and the burdens upon that which is not domestic are imposed equally upon ail."

The next case which involved the rule appeared in Illinois four years later. ${ }^{34}$ A statute of that state made it unlawful for a railroad comfany to deliver grain at any warehouse other than the one to which it was consigned, without the consent of the owner or consignee. The railroad, while delivering grain at a certain other warehouse without additional charge, demanded five dollars per car in addition to the regular rate for delivery at the warehouse of the plaintiffs. A petition for an ir junction against the exaction of this charge was granted. The bill contained an averment that the charge for delivery was intrinsically excessive and unreasonable, but the court in its opinion did not advert to the inherent reasonableness of the rate. It said: "As to the right of the company to impose the extra charge of five dollars, on the ground that it is performing additional service, it need only be said that a railway company, atthough permitted to establish its rates of transportation, must do so without unjust discrimination as to individuals," and enjoined the carrier from "imposing upon them (the plaintiffs) an additional charge for such delivery, beyond what it imposed upon other warehousemen." Here again the broad rule against unjust discrimination is laid down; and again the case is treated like one of first impression, none of the earlier cases or dicta being cited.

In the year 1870 two cases of importance in tracing the origin of the rule were decided, one of them by the Supreme Court of Pennsylvania, reported in the Legal Gazette of that year and not included in the official reports. ${ }^{25}$ In this case Mr. Justice Agnew charged that the carrier was bound to carry the coal of the complainant at a rate as low as the carrier was at the same time charging the "siost favored operators" for coal carried between the same points. While accepting the rule as a

"Vincent v. The Chicago \& Alton R. R., 49 III. 33 (1868).

- Coal Co. v. Railroad Company, 2 Legal Gazette (Pa.) 149 (1870). 
common law proposition, the court held that it did not preclude the possibility of a minimum charge, which was a discrimination founded upon sound principles and not unjust.

In the same year Chicago \& Northern Railway v. People, an Illinois case, presents the first instance in America where the problem of discrimination in the matter of facilities as distinguished from rates, was raised. The complaint was that the railroad had refused to deliver grain in bulik at the elevator of the plaintiff, while it made such deliveries for others, and a mandamus was sought to compel delivery at the plaintiff's elevator. Since a statute had rendered such delivery obligatory, as indicated in the Vircent Cose, 27 it is questionable whether that portion of the court's opinion dealing with the common law upon the subject of unjust discrimination can rise to a higher dignity than dicta. The court, while recognizing the effect of the statute, is emphatic in its opinion that independently of this legislative direction, an equivalent common law obligation would exist. The court's language is worth quoting :as

"Regarded merely as a common carrier at common law, and independently of any obligations imposed by the acceptance of its charter, it would owe important duties to the public, from which it sould not release itself, except with the consent of every person who might call upon it to perform them. Among these duties, as well defined and settled as anything in the law, was the obligation to receive and carry goods for all persons alike, without injurious discriminations as to terms, and to deliver them in safety to the consignee, unless prevented by the act of God or the public enemy. These obligations grew out of the relation voluntarily assumed by the carrier toward the public, and the requirements of public policy

- "Regarded then merely as a common carrier at common lasw" the respondent should not be permitted to say that it will deliver goods at the warehouse of $A$ and $B$, but will not deliver-at the warehouse of $C$, the latter presenting equal facilities for the discharge of freight, and being accessible on respondent's line"

It is noteworthy that the court did not seek to enforce the

"s6 IIL. 365 (1870).

- Supra, note 34

- At p. 378

- Italics not found in original 
duty as a part of the carrier's "duty to surve" but emphasized the discriminatory feature, the fact that service ac'as accorded to others similarly situated. As the first clear case of discrimination in facilities in America, this decision occupies an important place in the history of the origin of the rule against unjust discrimination.

The constitution adopted in Illinnis in 1870 empowered the general assembly to pass laws to prevent "unjust discrimination" lo. railroads." In Chicago \& Alton Railroad v. Pcople," in 1873, Mr. Chief Justice Lawrence held that an act providing for equal charges for equal distances was prohibitive of all differences and not merely of "unjust discriminations" as the constitution had authorized; but it was further stated that since tuijust or unreasomble discrimination was prohibited by the common law, subject to which all railroad charters were accepted, the charter rights of the railroad would not be infringed nor the contract impaired by an act prohibiting unjust discrimination.

From the foregoing analysis it is apparent that the common law rule prohibiting unjust discrimination had become established in America several years prior to the Messenger Case in $1874^{.2}$ Curiously enough, however, in the Messctiger Case nume of this carlier authority is referred to, and the only authorities therein cited stand for an entirely different principle.

It was about this tine that the clamur for regulation and legislative enforcement of the rule arose. One by one the states adopted legislative measures varying in severity and eficiency, which were immediately lauded and denounced respectively by the opposing schools of economists. However well established the common law prohibition against unjust discrimination may have been, practical difficultics in its application and enforcement created the demand for a more efficient method through the avenue of legislation. One fact, however, is to be emphasized, as it is commonly overlooked or denied. It was not

- Arr XI, Sec. 15.

"G7 III. II (1873).

- Messenger v. P. R. R., supra, note 26. 
due to any defect in the theory of the common law that the need for 2 statutory remedy arose. The American common law had developed a perfectly efficient theory, which has been taken over. uniformly in substance ard frequently in its precise phraseology. the term "unjust discrimination," in the modern statutes. It was rather the inadequacy of the common law processes and the abserice of any such administrative tribunals as the commissions of today for the enforcement of the duty in complicated situations, that created the need for legislation.

In the meantime, side by side with the statutory regulation, the development of the common law rule continued uninterrupted ${ }^{12}$ Arbitrary discriminations by public servants not included within the new acts gave rise to a great body of common law upon the subject and repeated reiterations of the rule"

A comparatively recent case deserves attention because in it the rule against unjust discrimination was based upon a novel ground.5 A gas company was engaged in supplying light to the residents of a town under the authority of a town ordinance which prescribed the terms under which such corporations might lay and maintain pipes in the streets, and provided that it should have the right, if it furnished a meter, to charge "any consumer" according to a certain rate. One consumer complained that the company would furnish him gas only on the meter basis, while "flat rates" were offered to other consumers. The court held that under the equal protection clause of the Fourteenth Amendment of the Federal Constitution neither the state nor its municipal subdivisions had power to authorize or permit

-In Hays v. P. R. R, 12 Fed 309 (I882), and Samuels v. Louisville \& N. R. $\mathrm{CO}_{3} 31$ Fed 57 (1887), the rigor with which the rule was applied is well illustrated. In the former case quantity as a justification for discrimination was repudiated; in the latter, the immateriality of the reasonableness of the higher of unequal rates was emphasized.

"Typical cases are those involving tank cara, State r. C. N. O. \& T. R. Ry. $\mathrm{Co}_{2} 47$ Ohio 130 (1890); ges companies, Owensboro Gaslight $\mathrm{Co}_{\text {. }}$. Hildebrand 19 Ky. Law Rep. 083 (1897); dectric companies, Snell v. Clinton Elect. Light Co, 196 III 626 (1002); Armour Packing Ca. r. Edison Elee. Illum. Co, 115 App. Div. (N. Y.) 51 (1906); water companies, Grifin v. Water Co, 122 N. C 206 (1898); sewers, Mobile v. Brenvilie Water Co., 130 Ala 379 (I900).

- Indiarta, etc., Gas Ca. r. State, I58 Ind. 516 (I901). 
arbitrary and burdensome discriminations between its inhabitants in the conduct of a business public in character. An ordinance could not, therefore, constitutionally authorize the exaction by a public servant of a certain rate from "any consumer," if that rate involved an arbitrary discrimination, since a state cannot clothe its subdivisions with power to evade a constitutional amendment. The case apparently conceives the duty to refrain from unjust discrimination to be one imposed by the amendment, or it at least decides that the amendment has made the common law prohibition unalterable. Whether under this theory a public servant operating without franchises of any kind would be similarly restrained is questionable. Certain it is that to call such a servant a state agency or a quasi state agency, even where a franchise is present, is far-fetched.

The point raised here appears never to have been decided elsewhere. If the view is sound, it opens up a horde of striking and practically interesting possibilities. If freedom from unjust discrimination is secured by the Fourteenth Amendment, an alleged infringement of this right involves a federal question. To mention a single illustration, may a shipper who alleges unjust discrimination, when the decision of the state court of last resort is adverse, appeal to the Supreme Court of the United States on the ground that a federal right has been violated? It has not been attempted. There is little probability that it would succeed.

While the rule against unjust discrimination was growing up at common law, some courts were arriving at the desired end by an indirect method. If two shippers under identical or substantially identical circumstances are given unequal rates, the natural inference is that the lower rate is remunerative and that therefore the higher must be excessive. This is not necessarily true. But it was quite natural that where such an inequality was shown to exist it should be accepted by the courts as some avidence, at least, that the higher rate exceeded the privilege of reasonable compensation. It was likewise natural that there should have been a desire on the part of some courts to enforce the right to equal treatment through the obligation to serve for 
reasonable compensation, a duty long-established and universally recognized, rather than through the medium of the rule against unjust discrimination, more recent of origin and of more dubious ancestry. As early as the case of $M c D$ uffee $\nabla$. Railroad, 18 in 1873 , it was said by way of dictum that such inequality might be evidence tending to show that the higher charge was excessive. This suggestion was seized upon by several courts which, though reluctant to accept the lately recognized common law rule against unjust discrimination, sometimes out of deference for the early English dicta, were nevertheless anxious to reach its result, even by indirection. The climax of what might be called the legal hypocrisy of this attitude, is reached in Cook v. Chicago, etc., Railway, ${ }^{47}$ where, after stating that ineuality of charges is only evidence to show that the higher rate is unreasonable, which is a perfectly legitimate inference, and after further quoting authorities to the effect that no obligation to refrain from unjust discrimination exists at common law, the court cites with approval Redfield on Law of Railroads ${ }^{48}$ to the effect that "carrying for reasonable compensation must imply that the same compensation is accepted always for the same service, else it could not be reasonable, either absolutely or relatively." It concludes that the only finding that can in fairness be made is that, after deducting the rebate, the rate was reasonable. Thus the court, in its zeal to enforce equality of rates, had given what was originally a bit of evidence the force of a conclusive presumption. The reasoning is ridiculous. The lesser rate may either as a matter of favor or of business policy have been placed below the rate necessary to secure 2 reasonable return, and to compel an uniform application of thelower rate may amount to unconstitutional confiscation. The reasonableness of the rate depends upon considerations that are intrinsic rather than relative. It is in the field of relative equality that the rule against unjust discrimination has its application.

- 52 N. HI. 430 (1873).

- 8I la 551 (1800).

- Vol. 2 , p. 95 . 
It were far better if the court had recognized this and accepied the rule.

It cannot be said that the enforcement of equality of rates under the presumption of the unreasonableness of the higher rate represents a distinct intermediate step in the development of the rule against unjust discrimination, as has sometimes been suipposed. When that suggestion was first made in the $M C^{-}$Duffee Case, in 1873, the common law rule had baer fully worked out and applied by some of the American courts, though its recognition was not quite general, and a year later the famous Messenger Case ${ }^{10}$ affirmed the rule. The cases decided on the theory that the higher of two unequal rates is presumptively unreasonable all arose later and represent an indirect attempt to attain the end of the rule against unjust discrimination by-courts reluctant to accept it after it had become thoroughily established. ${ }^{\text {so }}$

In spite of all this authority to the contrary, some courts even in recent times have declared that no common law obligation to refrain from unjust discrimination exists, and have cited Fitchburg Railroad v. Gage, ${ }^{51}$ decided in Massachusetts in 1859 , wherein the existence of any such obligation was denied. It remains, therefore, to determine the precise extent to which that view has received sanction in the American conmon law. HCw few of the cases, usually cited as having adopted the rule of the Gage Case, which actually support the broad principle there laid down, will appear presently.

Of these decisions, that in Johnson v. Pensacola Railroor "s is the earliest and easily the most carefully considered. In this

- Supra, notes 26 and 42

"Mr. Wyman, in his work on "Public Service Corporations," refers to what he calls 2 "later rule against unreasonable differences" as an intermediate step between the rule of the Gage case and the modera rule prohibiting unjust discrimination. Vol, 2, Sec 1283 . In view of the case of Twells v. Penna. R. R. and the other early cases already cited it seems safe to assert that the rule, in its present common lav form, arose full-Eedged, howrever closely the scope of it3 application, at the early law, may have been circumseribed A number of modern cases exhibiting the same tendenes are collected under Sec 1286 in the same volume.

12 Gray (Mass.) 393 (1859).

- 16 Fi2. 623 (2878). 
case lower rates on lumber were given to certain shippers in consideration of certain money lent to the railroad and a certain volume of shipping supplied. A shipper sued to recover the amount of freight he had paid in excess of what he would have paid under the rates allowed favored shippers. After citing the Gage Case and approving the statement therein that the common law obligation of carriers extends to the reasonableness of the rates only, and not to their equality, the court, in distinguishing the Messenger Case, was careful to say that there unequal rates were prohibited under the same circumstances, while in this case the declaration did not allege that the conditions were identical. The court further said that for all that appeared in this case the difference in rates might be justified by the amount of freight to be furnished by the parties, or other circumstances might render the conditions dissimilar, and upheld the discrimination. As a makeweight to bolster up its decision from the point of view of practicability, the court pointed out the inconvenience of a rule whereby a shipper who was unfairly treated might look about to discover the most favored shipper and recover according to the difference in the rates given them; the extent of the recovery would in effect be determined by the success attending such a search. Aside from the fact that the difficulty of arriving at a practicable measure of damages is not insuperable, and should not prevent the enforcement of a right to equality, if public policy recommends it, would the court have compelled by mandamus the imposition of equal rates in the future, if requested? In that case, at least, the praçtical objection would not be present.

A case often erroneously supposed to adhere to the doctrine of the Gage Case was decided four years later..$^{32}$ Here, again, an attempt was made to recover the excess where one shipper was charged more than another. After stating that the English sule permitted all discrimination, while in America unjust discrimination was prohibited, the court employs certain expressions indicating an adherence to the former view. Thus it says:

- Ragan v. Aiken, 9 Len. (Tenn.) 609 (1882). 
"A reasonable price paid by such 3 party is not made unreasonable by a less price paid by others," and quotes the English dictum, "The charging of another party too little is not charging you too much." st

The true ratio decidendi of the court appears in the concluding paragraph:

"If the charge on the goods of the party complaining is reasonable and such as the company would be required to adhere to as to all persons in like condition, it may, nevertheless, lower the charge of another person if it be to the advantage of the company. not inconsistent with the public interest, and based on a sufficient reasons. It is obvious that the intention of the defendant, in this instance, was not to discriminate against the complainants in favor of any persons of the same place and in the same condition. His object was to get business for his road from persons at 2. distance from its terminus, which otherwise would reach their destination by a different route. Under the circumstances, we cannot see that the contracts complained of are against public policy, or that the complainants have been damaged, if the charges on their goods were reasonable"

The presence of competition was expressly emphasized as a justification of the discrimination, in view of which it was neither unjust nor undue. Under its facts the case cannot be said to follow the Gage Case.

In two successive decisions in South Carolina the rule of the Gage Case was applied. In the first it was mentioned casually that the inducement was necessary in order to secure the freight for the carrier, a distinguishing fact, but this point was not emphasized. Quoting from the Gage Case and the Johnson Case, above referred to, the language of the opinion is broad enough to justify preferences under circumstances that are identical. A few years later the proposition was affirmed without discussion by the same court. ${ }^{\text {s? }}$

Another case often referred to as supporting the doctrine

"Garton v. B. \& E. R. R, I B. \& S. 112 (186r), swpro, note 12

- Italics not found in original.

- Ex parte Benson \& Co, 18 S. C 38 (1882).

- Avinger v. South Car. Ry., 29 S. C. 265 (1888). 
of the Gage Case clearly came to the opposite conclusion. section of the Colorado constitution prohibited "undue and unreasonable discrimination" by railroad companies, yet under it a contract allowing rebates to a favored shipper was upheld. It was said that it did not constitute unjust discrimination because it was not an exclusive contract and did not in terms prevent the allowance of similar privileges to others; and the specious distinction between a favor allowed to an individual which is de nied to others, and denying a certain individual privileges which others are permitted to enjoy, was apparently approved. But although it cited the Tennessee, Florida, and South Carolina cases heretofore referred to, the court also recognized the rule prohibiting unjust discrimination, and the Messenger Case, even though it may not have properly applied it. Nowhere, perhaps, is the confusion inevitably resulting from the use interchangeably of the terms "discrimination" and "unjust discrimination," better illustrated. In arriving at the conclusion that absolute equality was not imperative the courts found little difficulty. Certain differentiating circumstances would justify a difference or inequality. This absence of any obligation to preserve an absolute equality came to be termed, loosely, the right to "discriminate," and it was inaccurately stated by some courts that there was no rule against "discrimination." This confusion of "justifiable discrimination" with "unjust discrimination," resulting from the designation of both by the appellation, "discrimination," frequently led to the belief that the door to all kinds of discrimination had been opened. It is true that the Gage Case, with full knowledge of the consequences, went to that extent. But most of the cases which have purported to follow it lay down a much narrower principle.

As late as 1892 the Supreme Court of California was confronted with a case of rebating accompanied by no justifying circumstances, and held that such conduct was not prohibited by the common law.59 The court recognized the divergence of

- Bayles v. Kansas Pacific Ry, 13 Colo. 181 (1889).

- Cowden v. Pacific Steamship Ca, 94 Cal. 40 (189). 
opinion upon the subject in America, in view of which it preferred to follow the early English view. At this time, however, the rule had become firmly established in America, having the support of a great wealth of authority." This may be men. tioned as one of the few American cases which accept to the full extent the doctrine of the Gage Case.

The case of Lough v. Outerbridge," decided in an important commercial jurisdiction, has been confidently cited by courts and writers who adhere to the view of the Gage Case. It becomes important, therefore, to consider the ground of that decision. A certain steamship company offered a reduced rate to all who would patronize their ships exclusively while a competitor's ship was in port. This privilege was extended to all shippers under the same conditions. The court held that a shipper who patronized both the carrier in question and his competitor could not insist upon the lower rate. While the Gage Case was quoted by the court, the language of Mr. Justice O'Brien leaves beyond doubt the basis of the decision. ${ }^{2}$ He said: "If the general rates are reasonable a deviation from the standard by the carrier in favor of particular customers, for special reasons, not applicable to the whole public, does not furnish to parties not similarly situated any just grounds for cornplaint. When the conditions and circumstances are identical the charges to all shippers for the same service must be equal" The decision was arrived at on the ground that the rebate offered was not exclusive but was available to all upon the same con: ditions, and because the presence of competition justified this regulation on the part of the carrier. That the rule was fully accepted in New York is further indicated by 2 decision of the Court of Appeals of that state five years earlier in which the

- Concord \& Portsmouth R. R. v. Forsaith, 50 N. H. 122 (1875) : Hout ton, efc. Ry. v. Rust. 58 Tex. 98 (1882); Scofield v. Railway Co 43 Ohio ton, esc. Ry. Y. R. \& S. R. R. V. Ervin, 18 III. 250 (1886); Fitoperald v. $G$ and Trunk Ry. 53 Vt. 169 (1890). For a rodern case contaning an entensive review of the subject, see $\mathbf{M a}$. K. \& T. Ry. $\mathbf{r}$. New En Iifing $\mathrm{CO}, 80 \mathrm{Kan}$. 141 (I909).

143 N. Y. 27 (1894).

- On a 278. 
right of a carrier to make unjust discriminations either in service or in rates was denied. ${ }^{\text {es }}$

From the entire investigation it may safely be concluded that there grew up in America a common law doctrine prohibiting unjust discrimination as early as 1863 . While legislation to define and enforce the obligation appeared here much later than in England, the American courts had embodied the substance of what has become the modern statutory obligation into a common iaw rule. It represents a natural expansion of the obligations of public servants to satisfy a demand and correct an abuse which were the creatures of new and increasingly complicated conditions. And it further appears, upon close analysis of the decisions, that the English view, as announced in the Gage Case, has never acquired a real following among the cases, and cannot be said to have made any real impression upon the American common law.

\section{Benjamin M. Kline.}

Law School, University of Pennsytrania.

Roct v. L. I. R. R. Co, 114 N. Y. 300 (1889). Ir this case an interesting situation is presented. $A$ rebate on freight was offered in consideration of the erection by the shipper of a dock which the railroad could use. $A$ suit for the recovery of the rebates was successful. The court said that while the rebate standing alone would amount to an unjust discrimination, since it was founded upon valuable consideration the contract would be enforced The custom of giving rebates for consideration of indefinite value such as that in this case, later developed into a convenient cloak for unjust preferences, and the tendency of the courts under modern statutes is to frown upon it. At this time, however, it was held legitimate. 